\title{
sciendo
}

\section{THE EFFECT OF HYDROTHERMALLY PROCESSED SOYBEAN- AND RAPESEED-BASED DIETS ON PERFORMANCE, MEAT AND CARCASS QUALITY CHARACTERISTICS IN GROWING-FINISHING PIGS}

\author{
Piotr Kaczmarek¹, Daniel Korniewicz ${ }^{1}$, Krzysztof Lipiński , Magdalena Mazur-Kuśnirek² \\ ${ }^{1}$ Cargill Poland Ltd., Rolna 2/4, 62-280 Kiszkowo, Poland \\ ${ }^{2}$ Department of Animal Nutrition and Feed Management, University of Warmia and Mazury, \\ Oczapowskiego 5, 10-719 Olsztyn, Poland \\ •Corresponding author: krzysztof.lipinski@uwm.edu.pl
}

\begin{abstract}
The experiment was performed on 60 crossbred weaners with average initial body weight (BW) of $22 \mathrm{~kg}$. The animals were divided into 4 groups, with 15 animals (10 males and 5 females) per group, based on the percentage content of the following components in complete diets: soybean meal, toasted full-fat soybeans, cold-pressed rapeseed cake with increased oil content, extruded rapeseed cake with increased oil content. The growth performance of pigs, carcass characteristics, meat quality and the fatty acid profile of depot fat were determined. The pigs fed complete diets containing toasted soybeans had higher average daily gain (ADG). The animals receiving cold-pressed rapeseed cake were characterised by lower ADG and higher FCR. The carcasses of pigs fed diets containing cold-pressed rapeseed cake and extruded rapeseed cake had lower lean content than the carcasses of pigs administered toasted soybeans. The analysed feedstuffs had no effect on backfat thickness or meat quality. Cold-pressed and extruded rapeseed cake contributed to changes in the fatty acid profile of backfat, including an increase in the concentrations of monounsaturated fatty acids (MUFAs) and a more desirable $n-6 / n-3$ PUFA ratio. The extrusion processing of rapeseed cake decreased the content of lysine and methionine with cystine by approximately $4 \%$, and reduced total glucosinolate content by approximately $17 \%$. The inclusion of toasted soybeans in pig diets contributed to higher BW gain and carcass dressing percentage. Rapeseed cake with increased oil content led to desirable changes in the fatty acid profile of backfat.
\end{abstract}

Key words: pigs, rapeseed cake, soybean, carcass quality, fatty acid

Soybean meal, one of the most popular vegetable protein sources in animal feeds, is characterised by a high content of essential amino acids and high apparent ileal digestibility of protein (Chen et al., 2010). However, soybeans cannot be used as 
raw material for animal feed due to the presence of numerous antinutritional factors such as trypsin and chymotrypsin inhibitors, lectin and antigenic proteins (glycinin and $ß$-conglycinin). The antinutritional factors reduce nutrient digestibility and increase susceptibility to gastrointestinal disorders, particularly in piglets (Choct et al., 2010). The above antinutritional factors can be eliminated from soybeans during processing. The effectiveness of treatment is determined by heating temperature and time, the degree of fineness and moisture content of seeds (Nishinari et al., 2014).

World soybean production is estimated at 320 million tons per year. As a result, soybean meal production exceeds 200 million tons per year (Stein et al., 2016). Soybean meal has a higher global market share than other by-products from the vegetable oil industry. A rise in soybean prices and consumer concerns about the use of transgenic plants and genetically modified soybeans in animal feed prompt producers to search for alternative, cheaper sources of vegetable protein (Dzwonkowski and Bodyl, 2014; Rosiak, 2014).

The by-products of rapeseed processing could provide a viable alternative. Rapeseed production volume worldwide is approximately 71 million tons, and rapeseed meal production is estimated at 40 million tons (Stein et al., 2016). The use of rapeseed meal and rapeseed cake as protein sources in animal diets is on the rise in Poland. Due to the ban on GM animal feeds, rapeseed products can be considered as low-cost, locally available feed ingredients. The increasing popularity of rapeseed-based feeds can be attributed to the development of double-low varieties (with a reduced content of glucosinolates and erucic acid) and yellow-seeded varieties (with low fiber content) of oilseed rape as well as the use of rapeseed for biodiesel production (Brzóska et al., 2010; Stein et al., 2016). The chemical composition and nutritional value of rapeseed products vary depending on processing technology. The content of protein and oil in rapeseed cake is $25-31 \%$ and $9-21 \%$, respectively (Hanczakowska et al., 2012; Eklund et al., 2015). The biological value of rapeseed protein is comparable to that of soybean meal (Stein et al., 2016; Kargopoulos et al., 2018). However, genetic improvement, an increase in cultivation area and appropriate processing technologies are required to increase their inclusion levels in monogastric animal diets (Brzóska et al., 2010; Kaczmarek et al., 2016). Numerous studies have demonstrated the positive effects of partial replacement of soybean meal with rapeseed products in pig diets (Schöne et al., 2001; Hanczakowska and Świątkiewicz, 2014; Kargopoulos et al., 2018; Yun et al., 2018).

In view of the above, the following hypothesis was postulated: cold-pressed rapeseed cake or extruded rapeseed cake with increased oil content can partially replace soybean meal in pig diets without compromising their performance and meat quality. The aim of this study was to compare performance and carcass characteristics in growing-finishing pigs fed control complete diets containing soybean meal and soybean oil, and experimental complete diets where soybean meal and soybean oil were replaced with toasted full-fat soybeans, cold-pressed rapeseed cake or extruded rapeseed cake with increased oil content. 


\section{Material and methods}

The experimental materials comprised 60 crossbred (sows - Polish Large White $\times$ Polish Landrace $) \times$ (boars - Hampshire $\times$ Pietrain $)$ weaners with average initial body weight $(\mathrm{BW})$ of $22 \mathrm{~kg}$. The animals were divided into 4 groups, with 15 animals (10 males and 5 females) per group, based on the percentage content of the following components in complete diets:

Group I - control, soybean meal and soybean oil;

Group II - experimental, toasted full-fat soybeans; soybeans were cleaned, ground and steam-toasted (temperature - up to $95^{\circ} \mathrm{C}$, humidity - up to $20 \%$ );

Group III - experimental, toasted full-fat soybeans until day 26 of fattening, cold-pressed rapeseed cake with increased oil content (21\%) on days 27-90 of fattening. Rapeseed cake with oil content of around $10 \%$ was obtained by cold pressing of winter oilseed seeds with the use of screw presses. Several technological tests were carried out to increase the oil content of rapeseed cake to $21 \%$;

Group IV - experimental, toasted full-fat soybeans until day 26 of fattening, extruded rapeseed cake with increased oil content (21\%) on days 27-90 of fattening. Rapeseed cake with oil content of around $21 \%$ was subjected to dry extrusion for a short period of time $(30 \mathrm{~s}$; temperature at the outlet of the extrusion chamber $145^{\circ} \mathrm{C}$, pressure $\left.-30 \mathrm{~atm}\right)$.

During the experiment, pigs received 3 types of complete diets: starter -1 st stage of fattening (26 days), grower - 2nd stage of fattening (34 days), and finisher - 3rd stage of fattening (30 days). The animals were individually fed complete diets in mash form. Body weight gains were determined on an individual basis after 26, 60 and 90 days of feeding. The levels of protein, amino acids, energy, minerals and vitamins in diets were consistent with the Polish edition of Nutrient Requirements for Swine (2015).

Pigs were individually fed complete diets in friable form, offered ad libitum, and the amount of feed was recorded in successive stages of the fattening period. Average daily gains, feed intake and feed consumption per $\mathrm{kg}$ of BW gain were monitored on an individual basis on days 26, 60 and 90. To control feed intake, the animals were kept in individual pens on slatted floor. Pigs had free access to water throughout the experiment.

Chemical analyses of complete diets were performed by standard methods (AOAC, 2005). The energy value of diets was calculated based on own analyses of feed components, and nutrient digestibility coefficients and formulas given in the Polish edition of Nutrient Requirements for Swine (2015) and CVB (2004). The fibre fraction was analysed using the Fibertec apparatus according to the method of Van Soest and Wine (1967) including acid detergent fibre (ADF) and neutral detergent fibre (NDF). The concentration of $\mathrm{Ca}$ in feed samples was determined by atomic absorption spectrophotometry (procedure 4.8.03; AOAC, 2005) and $\mathrm{P}_{\mathrm{av}}$ levels were measured with a spectrophotometer at $650 \mathrm{~nm}$ (procedure 3.4.11; AOAC, 2005). The glucosinolate content of diets containing rapeseed cake and rapeseed products was determined by the glucose release method (Heaney et al., 1988). The percentage composition and nutritional value of diets are presented in Table 1. 


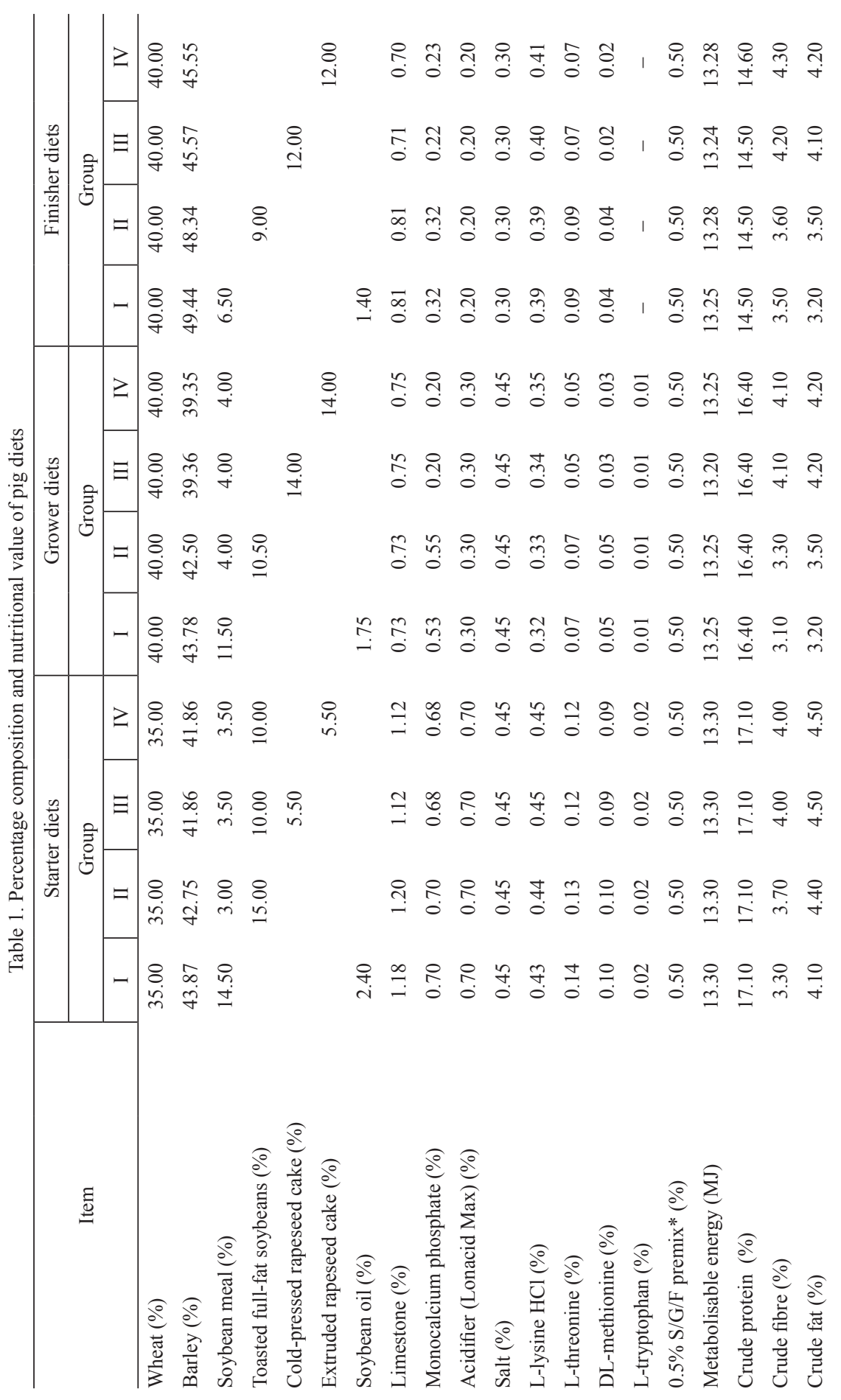




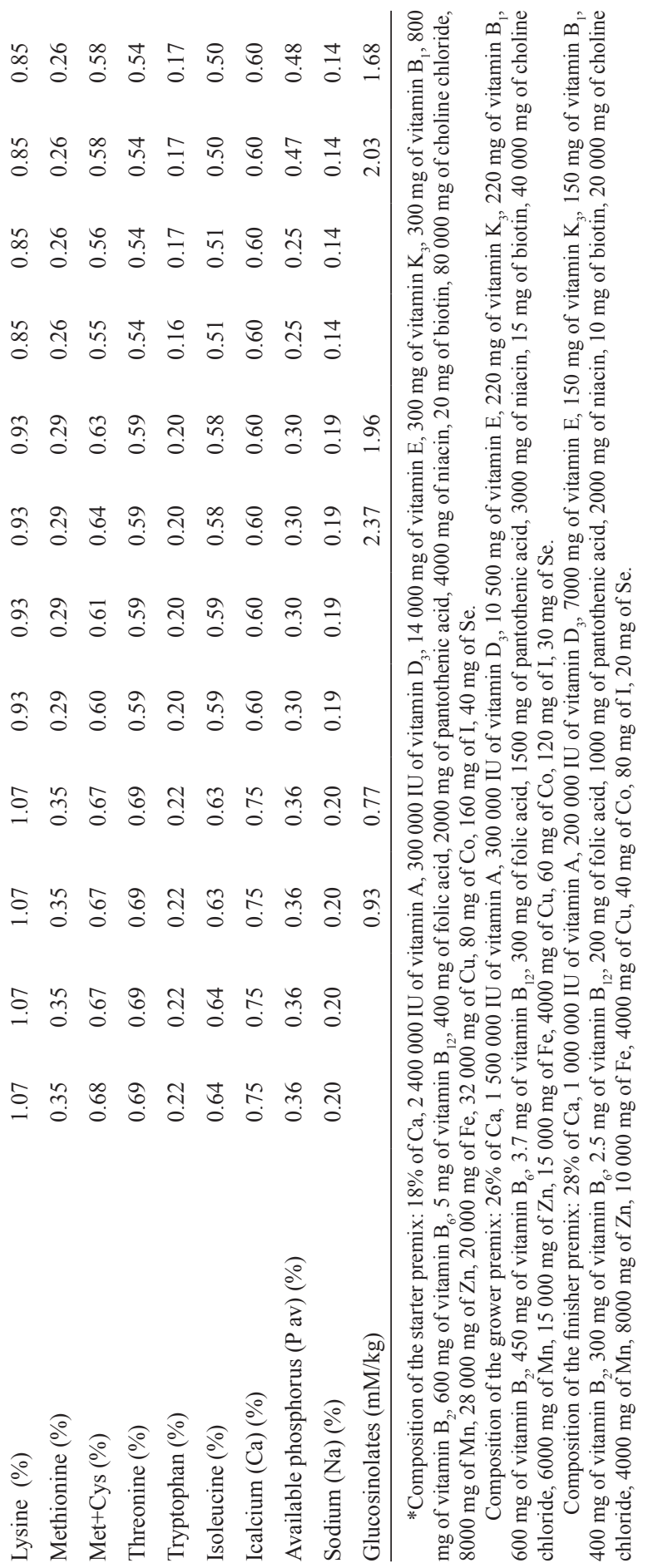


After 90 days of fattening, 48 pigs, 12 animals per group (8 males and 4 females) were slaughtered and carcass quality was evaluated. The following parameters were determined: carcass weight, carcass lean content (IM-03 pig carcass grading apparatus), backfat thickness - measured at 3 sites: shoulder, mid-back and loin (mean of five measurements), thickness of the gluteus medius muscle (GMP) - with the use of a cal-

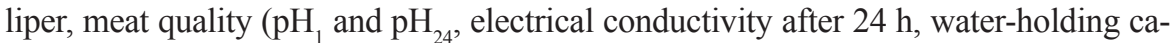
pacity, colour lightness, the height and width of the loin eye), and thyroid gland weight.

The values of $\mathrm{pH}$ were measured 1 and $24 \mathrm{~h}$ post mortem in the longissimus dorsi (LD) muscle at the level of the last rib and in the biceps femoris (BF) muscle (Radiometer PHM 80 portable $\mathrm{pH}$-meter with a combination electrode). Electrical conductivity $\left(\mathrm{EC}_{24}\right)$ was measured in the above muscles $24 \mathrm{~h}$ after stunning, with the MP-03 meter. Samples of raw meat were collected to determine water-holding capacity - by the Grau and Hamm method (1952) modified by Pohja and Niinivaara (1957), natural drip loss and cooking loss (Baryłko-Pikielna, 1975), and colour, including lightness L, redness a and yellowness b - with the Minolta CR 300 Chroma Meter.

Backfat samples were assayed for the concentrations of fatty acids by chromatography, including saturated fatty acids (SFAs), monounsaturated fatty acids (MUFAs), n-3 and $n-6$ polyunsaturated fatty acids (PUFAs), hypercholesterolemic fatty acids (OFAs), neutral and hypocholesterolemic fatty acids (DFAs), in accordance with the criteria proposed by Barowicz et al. (2000), and Leskanich and Noble (1997).

The results were processed statistically by one-way analysis of variance (ANOVA). The significance of differences between groups was estimated by Duncan's multiple range test using STATGRAPHICS v. 5.0 software.

\section{Results}

\section{Chemical analysis of soybean and rapeseed products}

The proximate chemical composition of cold-pressed rapeseed cake and extruded rapeseed cake is shown in Table 2. Extrusion processing increased dry matter content from $92.16 \%$ to $94.31 \%$. Extruded rapeseed cake contained approximately $29 \%$ crude protein, $21 \%$ fat and $10 \%$ crude fibre. An analysis of detergent fibre revealed that NDF and ADF accounted for approximately $20 \%$ and $16 \%$, respectively. Extrusion undesirably decreased the concentrations of selected amino acids. Rapeseed cakes were characterised by lower levels of SFAs and PUFAs, and over two-fold higher concentrations of MUFAs. Extruded rapeseed cake had lower total glucosinolate content (by approx. 17\%).

\section{Growth performance}

Pigs fed diets where soybean meal was replaced with toasted full-fat soybeans or extruded rapeseed cake had the highest final $\mathrm{BW}(\mathrm{P} \leq 0.05)$ (Table 3). Group II animals that received diets containing $15 \%$ of toasted full-fat soybeans had the highest ADG $(\mathrm{P} \leq 0.05)$ and the lowest daily feed intake $(\mathrm{P} \leq 0.05)$. Pigs fed cold-pressed rapeseed cake had higher average FCR than the remaining animals $(\mathrm{P} \leq 0.01)$. 
Table 2. Nutrient content of soybean and rapeseed products

\begin{tabular}{l|c|c|c|c}
\hline \multicolumn{1}{c|}{ Item } & $\begin{array}{c}\text { Soybean } \\
\text { meal }\end{array}$ & $\begin{array}{c}\text { Toasted } \\
\text { full-fat } \\
\text { soybeans }\end{array}$ & $\begin{array}{c}\text { Cold-pressed } \\
\text { rapeseed cake* }\end{array}$ & $\begin{array}{c}\text { Extruded } \\
\text { rapeseed cake** }\end{array}$ \\
\hline Dry matter (\%) & 89.98 & 90.68 & 92.16 & 94.31 \\
Crude protein (\%) & 46.40 & 35.32 & 28.57 & 29.39 \\
Crude fat (\%) & 1.70 & 20.39 & 21.20 & 21.70 \\
Crude fibre (\%) & 3.20 & 4.91 & 9.75 & 10.06 \\
ADF (\%) & 5.10 & 6.00 & 15.85 & 16.85 \\
NDF (\%) & 9.30 & 9.70 & 19.53 & 21.31 \\
Lysine (g/kg) & 30.80 & 22.20 & 17.10 & 16.50 \\
Methionine+Cystine (g/kg) & 12.40 & 10.30 & 12.40 & 11.90 \\
Threonine (g/kg) & 17.70 & 13.70 & 12.50 & 12.80 \\
Tryptophan (g/kg) & 6.10 & 4.90 & 3.90 & 4.00 \\
Calcium (\%) & 0.29 & 0.22 & 0.67 & 0.67 \\
Phosphorus (\%) & 0.65 & 0.48 & 0.94 & 0.94 \\
Sodium (\%) & 0.03 & 0.01 & 0.01 & 0.01 \\
SFAs (\%) & - & 16.60 & 8.80 & 8.00 \\
MUFAs (\%) & - & 23.90 & 61.90 & 62.90 \\
PUFAs (\%) & - & 59.50 & 29.20 & 14.00 \\
Glucosinolates $(\mu \mathrm{M} / \mathrm{g}$ non-fat DM) & - & - & 16.90 & \\
\hline & & & & \\
\hline
\end{tabular}

*Group III - toasted full-fat soybeans until day 26 of fattening, cold-pressed rapeseed cake with increased oil content $(21 \%)$ on days $27-90$ of fattening.

**Group IV - toasted full-fat soybeans until day 26 of fattening, extruded rapeseed cake with increased oil content $(21 \%)$ on days $27-90$ of fattening.

Table 3. Fattening performance - mean values for the fattening period

\begin{tabular}{|c|c|c|c|c|c|}
\hline \multirow[b]{2}{*}{ Item } & \multicolumn{4}{|c|}{ Group } & \multirow[b]{2}{*}{ SEM } \\
\hline & $\begin{array}{c}\text { I } \\
\text { Soybean } \\
\text { meal + soybean } \\
\text { oil }\end{array}$ & $\begin{array}{c}\text { II } \\
\text { Toasted } \\
\text { full-fat } \\
\text { soybeans }\end{array}$ & $\begin{array}{c}\text { III } \\
\text { Cold-pressed } \\
\text { rapeseed } \\
\text { cake* }\end{array}$ & $\begin{array}{c}\text { IV } \\
\text { Extruded } \\
\text { rapeseed } \\
\text { cake** }^{* *}\end{array}$ & \\
\hline 1 & 2 & 3 & 4 & 5 & 6 \\
\hline \multicolumn{6}{|l|}{ Weight gain (kg) } \\
\hline starter (int.- d 26) & 22.10 & 21.90 & 22.00 & 22.30 & 0.257 \\
\hline grower (d 27-60) & 43.80 & 45.50 & 44.70 & 44.80 & 0.414 \\
\hline finisher (d 61-90) & $75.41 \mathrm{a}$ & $80.30 \mathrm{~b}$ & $74.70 \mathrm{a}$ & $75.90 \mathrm{a}$ & 0.695 \\
\hline starter-finisher (int.-90) & 106.99 & $111.60 \mathrm{~b}$ & $102.70 \mathrm{a}$ & $107.60 \mathrm{~b}$ & 0.883 \\
\hline \multicolumn{6}{|c|}{ Average daily gain (ADG) (g/d) } \\
\hline starter (int.- d 26) & 830.77 & 907.00 & 853.00 & 865.00 & 12.242 \\
\hline grower (d 27-60) & $929.00 \mathrm{a}$ & $1023.53 \mathrm{~b}$ & $882.00 \mathrm{a}$ & $914.00 \mathrm{a}$ & 15.705 \\
\hline finisher (d 61-90) & 1053.00 & 1043.00 & 933.00 & 1056.00 & 19.241 \\
\hline starter-finisher (int.-90) & $943.22 \mathrm{a}$ & $996.00 \mathrm{Bb}$ & $896.67 \mathrm{~A}$ & 947.78 & 9.815 \\
\hline
\end{tabular}


Table 3 - contd.

\begin{tabular}{|c|c|c|c|c|c|}
\hline 1 & 2 & 3 & 4 & 5 & 6 \\
\hline \multicolumn{6}{|l|}{ ADFI $(\mathrm{kg} / \mathrm{p} / \mathrm{d})$} \\
\hline starter (int.- d 26) & 1.68 & 1.76 & 1.74 & 1.74 & 0.016 \\
\hline grower (d 27-60) & $2.38 \mathrm{a}$ & $2.52 \mathrm{~b}$ & $2.39 \mathrm{a}$ & $2.39 \mathrm{a}$ & 0.020 \\
\hline finisher (d 61-90) & 3.15 & 3.16 & 3.11 & 3.16 & 0.027 \\
\hline starter-finisher (int.-90) & 2.44 & 2.51 & 2.45 & 2.47 & 0.013 \\
\hline \multicolumn{6}{|l|}{ FCR $(\mathrm{kg} / \mathrm{kg})$} \\
\hline starter (int.- d 26) & 2.02 & 1.94 & 2.06 & 2.03 & 0.021 \\
\hline grower (d 27-60) & 2.56 & 2.46 & 2.71 & 2.60 & 0.032 \\
\hline finisher (d 61-90) & $2.99 \mathrm{~A}$ & $3.03 \mathrm{a}$ & $3.32 \mathrm{Bb}$ & $3.04 \mathrm{a}$ & 0.038 \\
\hline starter-finisher (int.-90) & $2.59 \mathrm{~A}$ & $2.52 \mathrm{~A}$ & $2.74 \mathrm{~B}$ & $2.61 \mathrm{~A}$ & 0.019 \\
\hline
\end{tabular}

$\mathrm{a}, \mathrm{b}-\mathrm{P} \leq 0.05 ; \mathrm{A}, \mathrm{B}-\mathrm{P} \leq 0.01$.

*Group III - toasted full-fat soybeans until day 26 of fattening, cold-pressed rapeseed cake with increased oil content $(21 \%)$ on days $27-90$ of fattening.

**Group IV - toasted full-fat soybeans until day 26 of fattening, extruded rapeseed cake with increased oil content (21\%) on days $27-90$ of fattening.

ADFI - average daily feed intake.

FCR - feed conversion ratio.

\section{Carcass and meat quality}

Pigs fed diets containing hydrothermally processed soybeans tended to have higher carcass dressing percentage and had the highest carcass lean content $(55.7 \%)$ in comparison with those administered cold-pressed rapeseed cake $(\mathrm{P} \leq 0.05)$ (Table 4).

The analysed feed components had no significant effect on backfat thickness, the height and width of the loin eye, the thickness of the gluteus medius muscle or thyroid gland weight.

Table 4. Pig carcass quality

\begin{tabular}{l|c|c|c|c|c}
\hline \multirow{2}{*}{ Item } & \multicolumn{4}{|c|}{ Group } & \multirow{2}{*}{ SEM } \\
\cline { 2 - 5 } & $\mathrm{I}$ & II & III & IV & \\
\cline { 2 - 5 } & $\begin{array}{c}\text { Soybean meal + } \\
\text { soybean oil }\end{array}$ & $\begin{array}{c}\text { Toasted full-fat } \\
\text { soybeans }\end{array}$ & $\begin{array}{c}\text { Cold-pressed } \\
\text { rapeseed cake* }\end{array}$ & $\begin{array}{c}\text { Extruded } \\
\text { rapeseed cake** }\end{array}$ & \\
\hline Dressing percentage (\%) & 81.31 & $82.09 \mathrm{x}$ & 81.08 & $80.63 \mathrm{y}$ & 0.205 \\
Lean content (\%) & 54.33 & $55.72 \mathrm{a}$ & $53.28 \mathrm{~b}$ & 54.41 & 0.317 \\
$\begin{array}{l}\text { Backfat thickness - mean } \\
\text { of 5 measurements (mm): }\end{array}$ & 22.01 & 23.29 & 20.96 & 22.96 & 0.412 \\
Loin eye height (mm) & 62.01 & 64.08 & 61.30 & 59.92 & 0.775 \\
Loin eye width (mm) & 83.83 & 89.83 & 86.58 & 88.58 & 1.515 \\
$\begin{array}{l}\text { Thickness of the gluteus } \\
\text { medius muscle (mm) }\end{array}$ & 68.42 & 69.51 & 66.67 & 66.84 & 122.29 \\
Thyroid gland weight (g) & 8.78 & 8.30 & 10.11 & 9.60 & 0.323 \\
\hline
\end{tabular}

$\mathrm{a}, \mathrm{b}-\mathrm{P} \leq 0.05 ; \mathrm{x}, \mathrm{y}-0.05<\mathrm{P} \leq 0.1$.

*Group III - toasted full-fat soybeans until day 26 of fattening, cold-pressed rapeseed cake with increased oil content $(21 \%)$ on days $27-90$ of fattening.

**Group IV - toasted full-fat soybeans until day 26 of fattening, extruded rapeseed cake with increased oil content $(21 \%)$ on days $27-90$ of fattening. 
The $\mathrm{pH}$ of meat was not affected by the protein feedstuffs used as substitutes for soybean meal, hydrothermal treatment or oil type (soybean oil, rapeseed oil) (Table 5).

The water-holding capacity was nearly identical in all dietary treatments, ranging from 32.28 to $32.60 \mathrm{~cm}^{2}$.

The analysed feed components had no influence on the values of electrical conductivity, natural drip loss or cooking loss.

Neither protein feedstuffs nor hydrothermal treatment exerted significant effects on colour lightness.

Table 5. Meat quality

\begin{tabular}{|c|c|c|c|c|c|}
\hline \multirow{3}{*}{ Item } & \multicolumn{4}{|c|}{ Group } & \multirow{3}{*}{ SEM } \\
\hline & \multirow{2}{*}{\begin{tabular}{|c|}
$\mathrm{I}$ \\
$\begin{array}{l}\text { Soybean meal } \\
+ \text { soybean oil }\end{array}$
\end{tabular}} & \multirow{2}{*}{\begin{tabular}{|c|} 
II \\
$\begin{array}{c}\text { Toasted full-fat } \\
\text { soybeans }\end{array}$ \\
\end{tabular}} & \multirow{2}{*}{$\begin{array}{c}\text { III } \\
\text { Cold-pressed } \\
\text { rapeseed cake* }\end{array}$} & \multirow{2}{*}{\begin{tabular}{|c|} 
IV \\
Extruded \\
rapeseed cake**
\end{tabular}} & \\
\hline & & & & & \\
\hline $\mathrm{pH}_{1}$ & 6.53 & 6.32 & 6.41 & 6.30 & 0.041 \\
\hline $\mathrm{pH}_{24}$ & 5.69 & 5.71 & 5.68 & 5.61 & 0.022 \\
\hline Electrical conductivity (mS) & 3.11 & 3.58 & 3.23 & 3.56 & 0.152 \\
\hline Water-holding capacity $\left(\mathrm{cm}^{2}\right)$ & 32.54 & 32.60 & 32.51 & 32.28 & 0.347 \\
\hline Cooking loss (\%) & 26.29 & 27.03 & 26.57 & 27.66 & 0.413 \\
\hline Natural drip loss (\%) & 4.99 & 5.40 & 5.09 & 5.54 & 0.308 \\
\hline Colour lightness & 50.50 & 50.86 & 51.14 & 50.92 & 0.394 \\
\hline Redness & 6.08 & 5.76 & 5.86 & 6.25 & 0.146 \\
\hline Yellowness & 1.60 & 1.85 & 1.88 & 1.87 & 0.115 \\
\hline
\end{tabular}

*Group III - toasted full-fat soybeans until day 26 of fattening, cold-pressed rapeseed cake with increased oil content (21\%) on days $27-90$ of fattening.

**Group IV - toasted full-fat soybeans until day 26 of fattening, extruded rapeseed cake with increased oil content $(21 \%)$ on days $27-90$ of fattening.

The concentrations of fatty acids in the backfat of pigs are presented in Table 6. Complete diets supplemented with toasted full-fat soybeans contributed to an increase in total SFAs $(\mathrm{P} \leq 0.05)$. No differences were found in the content of individual SFAs in backfat. Only the percentage of stearic acid (C18:0) tended to increase in group II animals fed diets with toasted full-fat soybeans. This resulted from the higher content of stearic acid in soybeans compared with oil contained in rapeseed cake.

The concentrations of MUFAs were higher in the backfat of pigs administered cold-pressed or extruded rapeseed cake than in the backfat of animals receiving soybean meal $(\mathrm{P} \leq 0.01)$. A detailed analysis of individual MUFAs revealed a highly significant $(\mathrm{P} \leq 0.01)$ increase in the content of the following acids: $\mathrm{C} 15: 1$; $\mathrm{C} 16: 1 n-9$; C18:1n-9 and C20:1 in the backfat of pigs fed rapeseed cake.

The total concentration of PUFAs was highest $(14.28 \%, \mathrm{P} \leq 0.01)$ in the backfat of control group animals (fed soybean oil). The observed differences were due to a higher content of linoleic acid (C18:2n- $)$ in control group pigs compared with the remaining animals $(\mathrm{P} \leq 0.01)$. Significant $(\mathrm{P} \leq 0.01)$ differences were also found in the 
percentage of a-linolenic acid (C18:3n-3), which was lowest in group II (0.60\%) and highest in groups III and IV (1.33\% and $1.48 \%$, respectively).

Table 6. Percentage content of fatty acids in backfat

\begin{tabular}{|c|c|c|c|c|c|}
\hline \multirow{3}{*}{ Fatty acids } & \multicolumn{4}{|c|}{ Group } & \multirow{3}{*}{ SEM } \\
\hline & \multirow{2}{*}{\begin{tabular}{|c|}
$\mathrm{I}$ \\
$\begin{array}{c}\text { Soybean meal }+ \\
\text { soybean oil }\end{array}$ \\
\end{tabular}} & \multirow{2}{*}{$\begin{array}{c}\text { II } \\
\begin{array}{c}\text { Toasted full-fat } \\
\text { soybeans }\end{array}\end{array}$} & \multirow{2}{*}{\begin{tabular}{|c|} 
III \\
Cold-pressed \\
rapeseed cake*
\end{tabular}} & \multirow{2}{*}{\begin{tabular}{|c|} 
IV \\
$\begin{array}{c}\text { Extruded rapeseed } \\
\text { cake** }\end{array}$
\end{tabular}} & \\
\hline & & & & & \\
\hline C10:0 & 0.10 & 0.10 & 0.10 & 0.10 & 0.001 \\
\hline C12:0 & 0.10 & 0.11 & 0.10 & 0.11 & 0.001 \\
\hline C14:0 & 1.66 & 1.69 & 1.60 & 1.65 & 0.032 \\
\hline C14:1 & 0.02 & 0.02 & 0.02 & 0.02 & 0.001 \\
\hline C15:0 & 0.05 & 0.05 & 0.06 & 0.05 & 0.003 \\
\hline C15:1 & $0.01 \mathrm{~A}$ & $0.01 \mathrm{~A}$ & $0.02 \mathrm{~B}$ & $0.02 \mathrm{~B}$ & 0.001 \\
\hline C16:0 & 27.62 & 28.33 & 27.48 & 27.36 & 0.238 \\
\hline $\mathrm{C} 16: 1 n-9$ & $0.34 \mathrm{~A}$ & $0.34 \mathrm{~A}$ & $0.46 \mathrm{~B}$ & 0.42 B & 0.011 \\
\hline $\mathrm{C} 16: 1 n-7$ & 2.06 & 2.05 & 1.83 & 1.80 & 0.066 \\
\hline C17:0 & 0.24 & 0.25 & 0.23 & 0.21 & 0.008 \\
\hline $\mathrm{C} 17: 1$ & 0.20 & 0.21 & 0.16 & 0.15 & 0.011 \\
\hline C18:0 & 14.41 & $16.08 \mathrm{x}$ & $14.42 \mathrm{y}$ & $14.01 \mathrm{y}$ & 0.301 \\
\hline $\mathrm{C} 18: 1 n-9$ & $34.83 \mathrm{Aa}$ & $36.85 \mathrm{~b}$ & $38.12 \mathrm{~B}$ & $38.28 \mathrm{~B}$ & 0.343 \\
\hline C18:1n-7 & 2.35 & 2.41 & 2.56 & 2.64 & 0.053 \\
\hline C18:2n-6 & $13.06 \mathrm{~A}$ & $9.34 \mathrm{~B}$ & $9.54 \mathrm{~B}$ & $9.84 \mathrm{~B}$ & 0.276 \\
\hline C18:3n-6 & $0.05 \mathrm{a}$ & $0.05 \mathrm{a}$ & 0.04 & $0.04 \mathrm{~b}$ & 0.001 \\
\hline C18:3n-3 & $1.14 \mathrm{~B}$ & $0.60 \mathrm{~A}$ & $1.33 \mathrm{Ca}$ & $1.48 \mathrm{Cb}$ & 0.052 \\
\hline CLA & $0.04 \mathrm{~A}$ & $0.06 \mathrm{~B}$ & $0.04 \mathrm{~A}$ & $0.04 \mathrm{~A}$ & 0.002 \\
\hline C20: 0 & 0.21 & 0.24 & 0.24 & 0.23 & 0.006 \\
\hline C20: 1 & $0.66 \mathrm{~A}$ & $0.82 \mathrm{~B}$ & $0.91 \mathrm{~B}$ & $0.88 \mathrm{~B}$ & 0.022 \\
\hline SFAs & $44.40 \mathrm{~b}$ & $46.84 \mathrm{a}$ & $44.23 \mathrm{~b}$ & $43.71 \mathrm{~b}$ & 3.006 \\
\hline MUFAs & $40.48 \mathrm{~A}$ & 42.72 & $44.07 \mathrm{~B}$ & $44.21 \mathrm{~B}$ & 2.894 \\
\hline PUFAs & $14.29 \mathrm{~B}$ & $10.05 \mathrm{Aa}$ & $10.95 \mathrm{~A}$ & $11.41 \mathrm{Ab}$ & 2.049 \\
\hline$n-3$ & $1.14 \mathrm{~B}$ & $0.60 \mathrm{~A}$ & $1.33 \mathrm{Ca}$ & $1.48 \mathrm{Cb}$ & 0.365 \\
\hline$n-6$ & $13.11 \mathrm{~A}$ & $9.39 \mathrm{~B}$ & $9.59 \mathrm{~B}$ & $9.89 \mathrm{~B}$ & 1.917 \\
\hline$n-6 / n-3$ & $11.54 \mathrm{~B}$ & $15.67 \mathrm{~A}$ & $7.23 \mathrm{Ca}$ & $6.67 \mathrm{Cb}$ & 3.751 \\
\hline DFAs & 69.17 & 68.57 & 69.44 & 69.62 & 1.777 \\
\hline OFAs & 29.29 & 30.02 & 29.09 & 29.01 & 1.837 \\
\hline DFA/OFA & 2.36 & 2.28 & 2.39 & 2.40 & 0.202 \\
\hline
\end{tabular}

$\mathrm{a}, \mathrm{b}-\mathrm{P} \leq 0.05 ; \mathrm{A}, \mathrm{B}-\mathrm{P} \leq 0.01 ; \mathrm{x}, \mathrm{y}-0.05<\mathrm{P} \leq 0.1$

SFAs - saturated fatty acids.

MUFAs - monounsaturated fatty acids.

PUFAs - polyunsaturated fatty acids.

DFAs - neutral and hypocholesterolemic fatty acids (UFAs+ C18:0).

OFAs - hypercholesterolemic fatty acids (SFAs - C18:0).

*Group III - toasted full-fat soybeans until day 26 of fattening, cold-pressed rapeseed cake with increased oil content $(21 \%)$ on days $27-90$ of fattening.

**Group IV - toasted full-fat soybeans until day 26 of fattening, extruded rapeseed cake with increased oil content $(21 \%)$ on days $27-90$ of fattening. 
The backfat of pigs fed diets with cold-pressed or extruded rapeseed cake had the highest content of $n$ - 3 PUFAs ( $\mathrm{P} \leq 0.01$ ), accompanied by a lower content of $n-6$ PUFAs relative to the control group (soybean oil) $(\mathrm{P} \leq 0.01)$. As a result, a desirable change was noted in the $n-6 / n-3$ PUFA ratio, which decreased from 11.54 in the control group to 7.23 in group III and 6.67 in group IV $(\mathrm{P} \leq 0.01)$.

No differences in the concentrations of neutral and hypocholesterolemic fatty acids (DFAs) or hypercholesterolemic fatty acids (OFAs) were found between the groups.

\section{Discussion}

\section{Chemical analysis of soybean and rapeseed products}

The nutritional value of rapeseed cake is mostly determined by the quality of seeds subjected to deoiling and the applied technological process (Grageola et al., 2013; Liu et al., 2014). In the current study, the extrusion of rapeseed cake reduced its total glucosinolate content by around 17\%. A beneficial influence of the hydrothermal process on a decrease in the levels of antinutritional factors in rapeseed products was also observed by Kaldmäe et al. (2010) and Liu et al. (2014).

In this experiment, both types of rapeseed cake had comparable concentrations of the analysed amino acids, but the concentrations of lysine and methionine with cystine were lower in extruded rapeseed cake. Similar results were reported by Seneviratne et al. (2014) who found that cold-pressed rapeseed cake heated at $60^{\circ} \mathrm{C}$ contained $20 \%$ less lysine than cold-pressed cake not subjected to heating.

\section{Growth performance}

Our findings indicate that extruded rapeseed cake with increased oil content can be a viable alternative to soybean meal and soybean oil as a source of protein and energy in pig diets. The values of the analysed performance parameters in growingfinishing pigs were lower in studies conducted by other authors where soybean meal was replaced with rapeseed cake with lower oil content and higher glucosinolate content. In the present experiment, the glucosinolate content of finisher diets containing $12 \%$ rapeseed cake was only 2.03 and $1.68 \mathrm{mM} / \mathrm{kg}$.

Gjerlaug-Enger et al. (2015) noted a decrease in BW gain and feed intake in pigs fed diets containing 13\% rape expeller and 5.6\% rapeseeds (total glucosinolates $1.12 \mu \mathrm{mol} / \mathrm{g}$ ). Similar results were reported by Schöne et al. (2001) who observed lower feed intake and BW gain in pigs receiving $150 \mathrm{~g}$ rapeseed-press cake per $\mathrm{kg}$ diet, which corresponded to $3.2 \mathrm{mmol}$ glucosinolates per $\mathrm{kg}$ diet. The inclusion of $75 \mathrm{~g}$ rapeseed-press cake per $\mathrm{kg}$ diet caused no differences in feed intake or the growth rate of pigs. Hanczakowska and Świątkiewicz (2014), who replaced soybean meal with rapeseed cake and legume seeds in pig diets, found that ADG decreased only in pigs fed blue lupine and rapeseed-press cake. Weber et al. (2006) evaluated the nutritional value of rapeseed cake with a glucosinolate content of $20.4 \mu \mathrm{M} / \mathrm{kg}$ and rapeseed cake subjected to hydrothermal treatment whose glucosinolate content 
was reduced to $10.5 \mu \mathrm{M} / \mathrm{kg}$. The cakes, used as a substitute for soybean meal, had no significant effect on final BW, ADG, feed intake or FCR. In the group administered hydrothermally processed rapeseed cake, feed intake and feed intake per kg BW gain were similar to the values noted in our study in pigs fed extruded rapeseed cake (2.47 kg and $2.61 \mathrm{~kg}$, respectively). In a study by Seneviratne et al. (2010), expellerpressed canola meal led to a decrease in ADG and feed intake, whereas Yun et al. (2018) demonstrated that 4\% rapeseed meal used a substitute for soybean meal had no effect on ADG, average daily feed intake or the gain to feed ratio.

The results of the present study and the findings of our authors point to a high nutritional value of rapeseed cake subjected to hydrothermal treatment to reduce its glucosinolate content.

\section{Carcass and meat quality}

The percentage content of lean meat is an important indicator of pork carcass quality for economic, processing and nutritional reasons. In the current experiment, the carcasses of pigs fed cold-pressed rapeseed cake had the lowest lean content $(53.3 \%)$, whereas the carcasses of group 2 pigs fed diets with toasted soybeans had the highest lean content (55.7\%). No significant differences in carcass lean content were found between control group pigs receiving soybean meal $(54.3 \%)$ and pigs fed extruded rapeseed cake $(54.4 \%)$. All carcasses were classified into conformation classes $\mathrm{E}$ and $\mathrm{U}$ in the EU pork carcass classification system.

Seneviratne et al. (2010) reported that increasing dietary expeller-pressed canola meal $(7.5 ; 15 ; 22.5 \%)$ linearly decreased carcass dressing percentage and carcass fat content in grower-finisher pigs. In contrast, Gjerlaug-Enger et al. (2015) observed no effect of rapeseed products (rape expeller and rapeseeds) on lean meat percentage, carcass value or pork quality, Schöne et al. (2001) found no differences in carcass weight or lean meat content in pigs fed rapeseed cake, either. Hanczakowska and Świątkiewicz (2014) reported no differences in carcass traits or meat quality in finishing pigs, except for sensory attributes (yellow lupine contributed to less desirable aroma and taste of meat).

An analysis of the physicochemical properties of meat, including $\mathrm{pH}$, water-holding capacity, natural drip loss, colour and electrical conductivity revealed that the values of these parameters were not affected by the analysed feedstuffs.

The dietary protein and energy sources tested in this study influenced the fatty acid composition of backfat, which resulted mostly from the concentrations of fatty acids in feed components. Commercial pig diets, based on cereals and soybean meal, usually supply approximately 10 times higher amounts of $n-6$ fatty acids relative to $n$-3 fatty acids (Gjerlaug-Enger et al., 2015). The oil contained in rapeseed cake led to a significant increase in the total content of $n$ - 3 PUFAs, which is an important nutritional consideration (Bertol et al., 2013). Fatty acids of the $n-3$ family help prevent the development of lifestyle diseases such as cardio-metabolic and inflammatory disorders (Mozaffarian, 2008; Galli and Calder, 2009). $n$-3 and n-6 PUFAs compete with enzymes for binding sites and affect cell metabolism. The $n-6 / n-3$ PUFA ratio influences various processes at the cellular level, including cell growth, proliferation, apoptosis and survival (Schmitz and Ecker, 2008). Koczanowski et al. (2004) 
investigated the effect of dietary supplementation with $6 \%$ rapeseed oil on the fatty acid profile of backfat in pigs. The cited authors found that rapeseed oil contributed to a significant increase in MUFA concentrations from 43.6 to $45.5 \%$. In the group of PUFAs, the levels of linoleic acid (C18:2) and linolenic acid (C18:3) increased significantly. Their total share was 54\% higher than in control group animals fed diets without oil supplementation. Rapeseed oil significantly decreased the $n-6 / n-3$ PUFA ratio from 10.98 to 7.37 .

In the current experiment, the $n-6 / n-3$ PUFA ratio decreased from 11.54 in the control group (soybean meal + soybean oil) to 6.67 in the group fed extruded rapeseed cake. A similar $n-6 / n-3$ PUFA ratio in backfat was reported by Korniewicz et al. (2004) and Bertol et al. (2013) in pigs fed complete diets supplemented with $2 \%$ or 3\% rapeseed oil. A beneficial influence of rapeseed oil on the $n-6 / n-3$ PUFA ratio in intramuscular fat was also observed by Kołacz et al. (2004) and Korniewicz et al. (2006). Gjerlaug-Enger et al. (2015) noted a two-fold increase in the concentration of $\alpha$-linolenic acid in backfat and a more desirable $n-6 / n-3$ PUFA ratio in pigs fed concentrate based on low-glucosinolate rapeseed products (13\% rape expeller and $5.6 \%$ rapeseeds).

The results of our study and the findings of other authors indicate that rapeseed oil and the oil contained in rapeseed cake, fed to pigs, have a positive influence on the fatty acid profile of dietary animal fats and oils.

It can be concluded that the pigs fed complete diets containing toasted soybeans, as a substitute for soybean meal and soybean oil, had higher ADG. The animals receiving cold-pressed rapeseed cake were characterised by lower ADG and higher FCR. The carcasses of pigs fed diets containing cold-pressed rapeseed cake and extruded rapeseed cake had lower lean content than the carcasses of pigs administered toasted soybeans. The analysed feedstuffs had no effect on backfat thickness or meat quality. Cold-pressed and extruded rapeseed cake contributed to changes in the fatty acid profile of backfat, including an increase in the concentrations of MUFAs, a decrease in linoleic acid (C18:2n-6) content, an increase in $\alpha$-linolenic acid (C18:3n-3) content and a more desirable $n-6 / n-3$ PUFA ratio. The extrusion processing of rapeseed cake decreased the content of lysine and methionine with cystine by approximately $4 \%$, and reduced total glucosinolate content by approximately $17 \%$.

The inclusion of toasted soybeans in pig diets contributed to higher BW gain and carcass dressing percentage. Rapeseed cake with increased oil content led to desirable changes in the fatty acid profile of backfat.

\section{References}

AOAC (2005). Official Methods of Analysis of the Association of Official Analytical Chemists. 16th Edition, Arlington, Virginia, USA.

B a r ow i c z T., B r zó s k a F., P i e tra s M. (2000). Hypocholesterolemic effect of dietary fat in diets of growing pigs. Med. Weter., 56: 746-749.

B a ryłk o-Piki eln a N. (1975). Outline of sensory analysis (in Polish). WNT Warszawa.

B ertol T.M., Campos R.M., Ludke J.V., Terra N.N., Figueiredo E.A., Coldebel - 
1 a A. (2013). Effects of genotype and dietary oil supplementation on performance, carcass traits, pork quality and fatty acid composition of backfat and intramuscular fat. Meat Sci., 93: 507-516.

Brzóska F., Śliwinski B., Michalik-Rutkowska O. (2010). Rapeseed-based feeds and their contribution to the national protein supply and nutritional value (in Polish). Part 1. Wiad. Zoot., 48: $11-18$.

Chen C.C., Chiou P.W.S., Yu B. (2010). Evaluating nutritional quality of single stage- and two stage-fermented soybean meal. Asian-Australas. J. Anim. Sci., 23: 598-606.

Ch o c t M., Ders j a n t-Li Y., M c L e is h J., P e is ker M. (2010). Soy oligosaccharides and soluble non-starch polysaccharides: a review of digestion, nutritive and anti-nutritive effects in pigs and poultry. Asian-Australas. J. Anim. Sci., 23: 1386-1398.

CVB 2004. Veevoedertable 2004, Centraal Veevoederbureau, Lelystad, Holland.

D z w o n k ow s k i W., B o d y l M.R. (2014). Changes in demand for protein feed in the context of the development of animal production and the situation on the world market for raw materials of high protein. Zesz. Nauk. SGGW Probl. Roln. Świat., 14: 5-15.

Eklund M., S a uer N., Schöne F., Messerschmidt U., Rosenfelder P., H too J.K., M o s e $\mathrm{n}$ th in R. (2015). Effect of processing of rapeseed under defined conditions in a pilot plant on chemical composition and standardized ileal amino acid digestibility in rapeseed meal for pigs. J. Anim. Sci., 93: 2813-2825.

G a 11 i C., C a 1 d e r P.C. (2009). Effects of fat and fatty acid intake on inflammatory and immune responses: a critical review. Ann. Nutr. Metab., 55: 123-139.

Gjerlaug-Enger E., Haug A., Gaarder M., Ljøkjel K., Stenseth R.S., Sigfrids on K., Eg e land sd a 1 B., S a are m K. B erg P. (2015). Pig feeds rich in rapeseed products and organic selenium increased omega-3 fatty acids and selenium in pork meat and backfat. Food Sci. Nutr., 3: 120-128.

Grage ola F., Landero J.L., B eltranena E., Cervantes M., Araiza A., Zijlstra R.T. (2013). Energy and amino acid digestibility of expeller-pressed canola meal and cold-pressed canola cake in ileal-cannulated finishing pigs. Anim. Feed Sci. Tech., 186: 169-176.

Gra u R., H a m m R. (1952). Eine einfache Metode zur Bestimmung der Wasserbindung in Fleisch. Fleischwirtschaft., 4: 295-297.

H a n c zakowska E., Światkiewicz M. (2014). Legume seeds and rapeseed press cake as replacers of soybean meal in feed for fattening pigs. Ann. Anim. Sci., 14: 921-934.

H a n c zakowska E., W ę g l arzy K., B e re za M. (2012). Effectiveness of rapeseed press cake (RPC) in sow feeding in two reproduction cycles. Ann. Anim. Sci., 12: 95-104.

H e a n e y R.K., S p in k s E.A., F e n w i ck G.R. (1988). Improved method for the determination of the total glucosinolate content of rapeseed by determination of enzymically released glucose. Analyst, 113: 1515-1517.

Ka czmarek P., Korniewicz D., Li piński K., Mazur M. (2016). Chemical composition of rapeseed products and their use in pig nutrition. Pol. J. Nat. Sci. 31: 545-562.

Kaldmä e H., Le m ing R., Kas s M., L e mber A., Tölp S., Kärt O. (2010). Chemical composition and nutritional value of heat-treated and cold-pressed rapeseed cake. Vet. Zootech-Lith., 49: $55-60$.

Kargopoulos A., D ot a s V., Gi an nen as I., Christaki E. (2018). Effect of dietary rape seed meal on growth performance and meat quality of growing-fattening pigs. S. Afr. J. Anim. Sci., 48: 897-906.

Koczanowski J., Orzechowska B., Migdał W. (2004). Fatty acid composition of backfat as affected by duration of feeding a diet with rapeseed oil. Rośliny Oleiste, 25: 307-313.

Kołacz R., Korniewicz A., Dobrzański Z., Bykowski P., Kołacz D., Korniew i c z D. (2004). Effect of dietary fish and rapeseed oils on sensory and physicochemical characteristic of pig $m$. longissimus dorsi and fatty acid composition. Anim. Feed Sci., 13: 143-152.

Korniewicz A., Dobrzański Z., Kołacz R., Korniewicz D., Usydus Z. (2004). The influence of fish and rapeseed oil on the fatty acid composition of backfat in pigs. Rocz. Nauk. Zoot. Supl., 20: 103-106.

Korniewicz A., Usydus Z., Kołacz R., Dobrzański Z., Kulok M., Kanderska J. (2006). Effect of halloysite on fatty acid composition in meat, liver and backfat. Acta Sci. Pol. Zootechnica 5: 49-58. 
L e s k a n i c h C.O., N o b l e R.C. (1997). Manipulation of the $n$-3 polyunsaturated fatty acid composition of avian eggs and meal. World Poultry Sci. J., 53: 155-184.

L i u Y., S ong M., Ma i s on T., S t e in H.H. (2014). Effects of protein concentration and heat treatment on concentration of digestible and metabolizable energy and on amino acid digestibility in four sources of canola meal fed to growing pigs. J. Anim. Sci., 92: 4466-4477.

M o z a ffarian D. (2008). Fish and $n-3$ fatty acids for the prevention of fatal coronary heart disease and sudden cardiac death. Am. J. Clin. Nutr., 87: 1991S-1996S.

N is h in ari K., F ang Y., Gu o S., Phill i p s G.O. (2014). Soy proteins: A review on composition, aggregation and emulsification. Food Hydrocoll., 39: 301-318.

Nutrient Requirements and Nutritional Value of Feeds for Swine (in Polish). 2nd Edition. Grela ER, Skomiał J (Editors). 2015. The Kielanowski Institute of Animal Physiology and Nutrition, PAS, Jabłonna (Poland).

Pohja N.S., Ni in iva a r a F.P. (1957). Bestimmung der Wasserbindung des Fleisches mittels der Konstantdruckmethode. Fleischwirtschaft., 9: 193-195.

R os iak E. (2014). The domestic market of rapeseed compared to the global market. Zesz. Nauk. SGGW Probl. Roln. Świat., 14: 86-96.

S ch mitz G., E c ker J. (2008). The opposing effects of $n-3$ and $n-6$ fatty acids. Prog. Lipid Res., 47: 147-155.

Schöne F., Tischendorf F., Le iterer M., Hartung H., B argholz J. (2001). Effects of rapeseed-press cake glucosinolates and iodine on the performance, the thyroid gland and the liver vitamin a status of pigs. Arch. Anim. Nutr., 55: 333-350.

Seneviratne RW., Young M.G., Beltranena E., Goonewardene L.A., Newkirk R.W., Zijlstra R.T. (2010). The nutritional value of expeller-pressed canola meal for grower-finisher pigs. J. Anim. Sci., 88: 2073-2083.

Seneviratne R.W., B eltranena E., Newkirk R.W., Goonewardene L.A., Zijls tr a E.T. (2011). Processing conditions affect nutrient digestibility of cold-pressed canola cake for grower pigs. J. Anim. Sci., 89: 2452-2461.

S t e in H.H., L a g o s L.V., C a s a s G.A. (2016). Nutritional value of feed ingredients of plant origin fed to pigs. Anim. Feed Sci. Tech., 218: 33-69.

Van S o e s t P.J., W in e R.H. (1967). Use of detergents in the analysis of fibrous feeds. IV. Determination of plant cell wall constituents. J. Assoc. Off. Anal. Chem., 50: 50-55.

Weber M., Stenzel P., S chöne F., Kleine Klausing H. (2006). Zum Einfluss von Rapskuchen (unbehandelt und thermisch behandelt) auf Leistung und Schilddrüsenstatus von Mastschweinen. 9 Tagung Schweine- und Geflügelernährung, 28-30.11.2006. Universitat Halle - Wittenberg, pp. 259-261.

Yun H.M., L e i X.J., L e e S.I., K i m I.H. (2018). Rapeseed meal and canola meal can partially replace soybean meal as a protein source in finishing pigs. J. Appl. Anim. Res., 46: 195-199.

Received: 16 XI 2018

Accepted: 8 VII 2019 